\title{
The Growth and Mineral Utilization of Clarias Gariepinus Fingerlings Fed Phytase-Supplemented Toasted Lima Bean (Phaseolus lunatus) Diets
}

\author{
Orisasona O* and Ajani EK \\ Department of Aquaculture and Fisheries Management, University of Ibadan, Ibadan, Nigeria
}

\begin{abstract}
Toasting causes slight reduction in the phytate content of Lima bean, thus requiring further treatment for effective utilization when incorporated into fish feed. The growth, mineral utilization and liver response of Clarias gariepinus fingerlings fed Toasted Lima Bean Meal (TLBM) diets supplemented with phytase was investigated. An Isonitrogenous diet ( $40 \%$ crude protein) was formulated with TLBM as a plant protein source. Phytase was added to diets post pelleting at 0 FTU (F1), 2500 FTU (F2), 5000FTU (F3), 7500FTU (F4) and 10,000FTU (F5). Feed were fed to triplicate groups of 15 fish $(1.43 \mathrm{~g} \pm 0.0012 \mathrm{~g})$ stocked in 25 liter capacity plastic tanks, cultured at a mean dissolved oxygen, $\mathrm{pH}$ and temperature of $5.37 \mathrm{mg} / \mathrm{l}, 7.2$ and $25.8^{\circ} \mathrm{C}$ respectively for 56 days. Mean weight gain and Feed conversion Ratio (FCR) were significantly $(P<0.05)$ higher in fish fed diets F3 and F4. Fish fed diets F4 had the highest Specific Growth Rate (SGR) 3.31, Protein Efficiency Ratio (PER) 1.78 and least FCR 1.41. The control (F1) gave the lowest SGR 2.79, PER 1.57 and highest FCR 1.6. There is increased phosphorus utilization with increased enzyme inclusion. Bone ash and phosphorus of fish showed mark increase with increasing level of phytase. Histopathological examination of fish revealed no negative effect of phytase on the liver of fish.
\end{abstract}

Keywords: Clarias gariepinus; Phytase; Lima bean; Phosphorus utilization

\section{Introduction}

Aquaculture is growing more rapidly than all other animal foodproduction sectors [1]. The current increase can be partly attributed to the wide availability and utilization of aqua-feeds, which has a growth rate in excess of 30 percent per year [2]. This growth is highly based on the utilization of fishmeal and fish oil, which contributes to the increasing cost of fish feed. The major challenge facing aquaculture industry is to identify economically viable and environmentally friendly alternatives to fishmeal and fish oil on which many present aqua-feeds are largely based [3]. The viable utilization of plant feedstuffs is therefore an essential requirement for future development of aquaculture.

Lima bean is an important source of plant protein, with a production capacity in excess of $2000 \mathrm{~kg} / \mathrm{h}$ reported [4]. It is well cultivated all across Nigeria and some African countries [5]. The utilisation of Lima bean in feed production like any other plant protein ingredient, is however limited with the presence of some anti-nutritional factors, notably phytate. Over $60 \%$ of phosphorus in plant feed stuffs are in the form of phytate [6], which is not available to monogastric animals because they lack intestinal phytase for its digestion. Inorganic phosphorus is thus required to be supplemented in diets to prevent deficiency. In addition to increasing cost of feed, the excretion of excess phosphorus in fish waste is also a major concern.

A number of processing methods have been employed to improve nutrient availability and utilization in fish, in order to expand the ingredients base for fish feed. Orisasona et al. [7] observed that Boiled Lima Bean Meal (BLBM) successfully replace 50\% SBM in the diets of C. gariepinus, though; boiling only slightly reduced the phytate content of BLBM. Other method(s) to ensure the complete elimination of phytate is therefore required. A method currently applied to overcome the challenge of phytate, is the use of phytase in breaking down the phytate-nutrient complexes to enhance release for the target organism [8]. Phytase have been applied into diets to liberate phytate phosphorus and make more utilizable phosphorus available for fish growth. Van Weerd et al. [9] reported a positive effect of phytase treatment using
Soy bean meal (SBM), particularly on phosphorus digestibility, retention and consequently its conversion efficiency and budget in African catfish. In the report, utilization was no however affected. This is however contrary to the observations of Rodehutscord and Pfeffer [10] and Schaeffer et al. [11] where positive effect of phytase on phosphorus utilization for rainbow trout and common carp were reported. A combination of some processing methods and phytase treatment to improve efficacy on SBM have been reported [12].

However, information on the combination of processing and phytase supplement on LBM is inadequate; therefore, this study was conducted to determine the effects toasted lima bean meal diets supplemented with phytase on the growth performance and mineral utilisation of Clarias gariepinus fingerlings.

\section{Materials and Methods}

\section{Diet preparation}

Lima bean seeds were sundried for 3 days and a portion of it heated at $240^{\circ} \mathrm{C}$ for 15 minutes in an oven. The Raw and the toasted beans were milled into fine particles. Raw (RLBM) and toasted (TLBM) meals were analysed for proximate composition (Table 1). A $40 \%$ crude protein (CP) \} diet was prepared using TLBM and other ingredients including fish meal, yellow maize, wheat offal and vitamins premix (Table 2). Finely ground ingredients were mixed thoroughly in a Hobart A200 (Troy Ohio USA) pelleting machine. The homogenized masses were

*Corresponding author: Orisasona O, Department of Aquaculture and Fisheries Management, University of Ibadan, Ibadan, Nigeria, Tel: +2348186523096; E-mail: osasonagbenga@gmail.com

Received May 26, 2015; Accepted June 15, 2015; Published August 18, 2015

Citation: Orisasona O, Ajani EK (2015) The Growth and Mineral Utilization of Clarias Gariepinus Fingerlings Fed Phytase-Supplemented Toasted Lima Bean (Phaseolus lunatus) Diets. J Aquac Res Development 6: 361. doi:10.4172/21559546.1000361

Copyright: (c) 2015 Orisasona O, et al. This is an open-access article distributed under the terms of the Creative Commons Attribution License, which permits unrestricted use, distribution, and reproduction in any medium, provided the original author and source are credited. 


\begin{tabular}{|c|c|c|}
\hline Components & Raw & Toasted \\
\hline \% Dry matter & 91.74 & 91.66 \\
\hline \% Crude protein & 23.56 & 23.76 \\
\hline \% Crude fibre & 5.86 & 4.97 \\
\hline$\%$ Ether extract & 1.73 & 1.79 \\
\hline$\%$ Ash & 3.96 & 3.91 \\
\hline$\%$ Moisture & 8.26 & 8.34 \\
\hline NFE & 56.63 & 57.23 \\
\hline \% Calcium & 0.47 & 0.38 \\
\hline$\%$ Phosphorus & 0.36 & 0.28 \\
\hline Trypsin Inhibitor & 32.66 & 0.00 \\
\hline TIU/mg Protein) & 9.12 & 4.12 \\
\hline Tannin $(\mathrm{g} / \mathrm{kg})$ & 3.2 & 2.9 \\
\hline Phytate $(\mathrm{g} / \mathrm{kg})$ & & \\
\hline
\end{tabular}

Table 1: Composition of Lima bean (Phaseolus lunatus).

\begin{tabular}{|c|c|c|c|c|c|}
\hline & \multicolumn{5}{|c|}{ DIETS } \\
\hline Ingredient & F1 & F2 & F3 & F4 & F5 \\
\hline Fishmeal & 36.31 & 36.31 & 36.31 & 36.31 & 36.31 \\
\hline Lima bean meal & 54.46 & 54.46 & 54.46 & 54.46 & 54.46 \\
\hline Yellow maize & 2.06 & 2.06 & 2.06 & 2.06 & 2.06 \\
\hline Wheat offal & 4.17 & 4.17 & 4.17 & 4.17 & 4.17 \\
\hline Vitamin premix & 1.0 & 1.0 & 1.0 & 1.0 & 1.0 \\
\hline Oil & 0.5 & 0.5 & 0.5 & 0.5 & 0.5 \\
\hline Salt & 0.5 & 0.5 & 0.5 & 0.5 & 0.5 \\
\hline Binder & 1.0 & 1.0 & 1.0 & 1.0 & 1.0 \\
\hline Total & 100 & 100 & 100 & 100 & 100 \\
\hline Phytase (g) & 0 & 0.5 & 1.0 & 1.5 & 2.0 \\
\hline Proximate composition $\%$ & & & & & \\
\hline Crude Protein & 39.93 & 39.95 & 39.81 & 39.82 & 39.90 \\
\hline Ether extract & 3.89 & 3.91 & 3.91 & 3.92 & 3.90 \\
\hline Crude fibre & 6.22 & 6.21 & 6.22 & 6.18 & 6.20 \\
\hline Ash & 7.69 & 7.70 & 7.60 & 7.75 & 7.79 \\
\hline NFE & 32.99 & 32.98 & 33.18 & 33.13 & 32.94 \\
\hline Phosphorus (mg/g) & 4.12 & 4.31 & 4.67 & 4.40 & 3.94 \\
\hline Table & & & & & \\
\hline Goss & & & & \\
\hline
\end{tabular}

Table 2: Gross and proximate composition level of experimental diets.

pelletized using starch paste as binder through a $2 \mathrm{~mm}$ die. Diets were divided into five (F1, F2, F3, F4 and F5) and $0.5,1.0,1.5$ and $2.0 \mathrm{~g} / \mathrm{kg}$ feed of granulated phytase \{Ronozyme P 5000 (CT) \} from Peniophora lycii were each dissolved in $40 \mathrm{ml}$ of distilled water and sprayed on the diets (F2, F3, F4 and F5 respectively), while F1 (Control) was sprayed with $40 \mathrm{ml}$ of distilled water to ensure uniform moisture. Feed were sundried for three days, packed in separate polythene bags and labeled. Feeds were kept in a refrigerator until needed.

\section{Experimental fish and culture condition}

A total of 225 C. gariepinus ( $1.43 \mathrm{~g} \pm 0.0012 \mathrm{~g}$ ) obtained from a reputable fish farm were acclimatized for 7 days in Department of Aquaculture and Fisheries Management laboratory, University of Ibadan. Fifteen fish were randomly stocked into triplicate plastic aquaria $(60 \mathrm{~cm} \times 40 \mathrm{~cm} \times 40 \mathrm{~cm})$ for each of the five treatments. Fish were fed at $5 \%$ body weight. Feed was divided into two equal parts; these were fed to the fish twice daily between $8.30 \mathrm{hr}-9.00 \mathrm{hr}$ and 17.30 $\mathrm{hr}-18.00 \mathrm{hr}$, for 56 days. Feed adjustments were made biweekly, after weighing of experimental fish. Water temperature, dissolved oxygen and $\mathrm{pH}$ were monitored weekly. Growth and nutrient utilisation were calculated according to Castell and Tiews [13].

\section{Chemical analysis}

Raw and toasted Lima bean meals, diets and fish (whole body) were analyzed for proximate and mineral compositions, using methods described by Association of Official Analytical Chemists [14].

\section{Histological preparations}

Two fish taken per treatment was decapitated to observe the liver for gross lesions. The livers were subjected to Lynch's laboratory procedures as described by Raphael.

\section{Statistical analysis}

Data resulting from the experiment were subjected to one way analysis of variance using the SPSS (Statistical Package Computer, Software 1988 version Chicago Illinois, USA). Duncan's multiple range test was used to compare differences among individual means at $\mathrm{P}=0.05$ [15].

\section{Results}

The results of the proximate, mineral and anti-nutritional factors in raw and toasted lima bean meals are presented in Table 3. Crude protein content was slightly higher in the toasted meal, while crude fibre and ash contents were marginally higher in the raw meal. Also there was a slight reduction in calcium and phosphorus content of toasted meal.

Trypsin inhibitor was completely eliminated from 32.66 TIU/ $\mathrm{mg}$ protein in the raw meal to $0 \mathrm{TIU} / \mathrm{mg}$ protein in the toasted meal. However, toasting did not completely eliminate tannin and phytate components. Crude protein content of experimental diets ranged from 39.81 to $39.95 \%$ as shown in Table 4 .

The carcass, proximate composition and mineral concentrations of experimental fish are presented in Tables 5 and 6. Crude protein was significantly higher $(\mathrm{P}<0.05)$ in all experimental fish when compared with the initial value. However, crude protein in F1 group was significantly lower $(\mathrm{P}<0.05)$ than other groups.

Phytase caused significant increase $(\mathrm{P}<0.05)$ in the ash contents of experimental fish. The lowest ash content of $6.75 \%$ was recorded in F1, while the highest values of $7.62 \%$ was observed in F4.

Fish fed diets F1 had similar zinc content as the initial that is significantly lower than fish fed phytase supplemented diets. With the exception of the statistical similarity in F1 and F3 groups, calcium was significantly higher and varied in fish fed diets F2, F4 and F5. Carcass manganese ranged from 19.63 to $27.36 \mu \mathrm{g} / \mathrm{g}$.

Fish in F1 and F2 groups had similar phosphorus concentration, that were significantly lower $(\mathrm{P}<0.05)$ than $\mathrm{F} 3, \mathrm{~F} 4$ and F5 groups.

The highest mean weight gain of $7.56 \mathrm{~g}$ was recorded in F4, with the control diet (F1) recording the lowest value of $5.66 \mathrm{~g}$. Weekly average weight gained in experimental fish is shown in Figure 1. Fish fed diets with phytase-supplementation produced significantly higher $(\mathrm{P}<0.05)$ weight gain and SGR when compared with fish fed diet F1. The SGR and PER were better in F3 and F4 groups than other groups.

Bone ash and phosphorus were significantly higher $(\mathrm{P}<0.05)$ in treatments with phytase-supplement. Results of the water quality analysis revealed values within the range recommended for the culture of C. gariepinus. Liver response showed the moderate presence of macrophage hyperplasia in fish fed diets $\mathrm{F} 1$ and F5, while lymphatic 
Citation: Orisasona O, Ajani EK (2015) The Growth and Mineral Utilization of Clarias Gariepinus Fingerlings Fed Phytase-Supplemented Toasted Lima Bean (Phaseolus lunatus) Diets. J Aquac Res Development 6: 361. doi:10.4172/2155-9546.1000361

Page 3 of 4

\begin{tabular}{|c|c|c|c|c|c|c|}
\hline \multirow[t]{2}{*}{ Parameter \% } & \multirow[t]{2}{*}{ Initial } & \multicolumn{5}{|c|}{ After Trials/Treatments } \\
\hline & & F1 & F2 & F3 & F4 & F5 \\
\hline Crude Protein & $50.59 \pm 0.00^{a}$ & $51.28 \pm 0.03^{b}$ & $53.73 \pm 0.00^{e}$ & $51.92 \pm 0.04^{c}$ & $54.62 \pm 0.00^{f}$ & $52.61 \pm 0.32^{d}$ \\
\hline Crude fibre & $1.83 \pm 0.03^{a}$ & $3.73 \pm 0.05^{b}$ & $4.95 \pm 0.18^{d}$ & $4.78 \pm 0.00^{d}$ & $3.97 \pm 0.00^{c}$ & $3.62 \pm 0.00^{b}$ \\
\hline Ether extract & $7.22 \pm 0.00^{d}$ & $4.77 \pm 0.00^{\mathrm{b}}$ & $4.92 \pm 0.00^{\mathrm{b}}$ & $5.14 \pm 0.01^{c}$ & $4.38 \pm 0.14^{a}$ & $5.26 \pm 0.01^{c}$ \\
\hline Ash & $9.44 \pm 0.00^{f}$ & $6.75 \pm 0.00^{\mathrm{a}}$ & $6.93 \pm 0.00^{b}$ & $7.44 \pm 0.05^{d}$ & $7.62 \pm 0.00^{\mathrm{e}}$ & $7.32 \pm 0.00^{c}$ \\
\hline NFE & $20.78 \pm 0.00^{c}$ & $22.78 \pm 0.00^{e}$ & $20.24 \pm 0.00^{\mathrm{a}}$ & $20.64 \pm 0.00^{b}$ & $20.65 \pm 0.00^{b}$ & $22.48 \pm 0.89^{e}$ \\
\hline Zinc $(\mu \mathrm{g} / \mathrm{g})$ & $22.00 \pm 0.00^{a}$ & $23.01 \pm 0.00^{\mathrm{a}}$ & $29.64 \pm 0.68^{d}$ & $27.03 \pm 0.02^{c}$ & $25.14 \pm 0.07^{b}$ & $31.33 \pm 0.00^{\mathrm{e}}$ \\
\hline Magnesium (mg/g) & $23.80 \pm 0.00^{d}$ & $17.62 \pm 0.30^{a}$ & $21.00 \pm 0.01^{c}$ & $19.37 \pm 0.21^{b}$ & $23.96 \pm 0.04^{d}$ & $26.75 \pm 0.36^{\mathrm{e}}$ \\
\hline Calcium (mg/g) & $17.31 \pm 0.14^{a}$ & $19.15 \pm 0.06^{b}$ & $19.67 \pm 0.01^{\mathrm{c}}$ & $18.90 \pm 0.10^{b}$ & $23.97 \pm 0.03^{e}$ & $23.59 \pm 0.04^{\mathrm{d}}$ \\
\hline Manganese $(\mu \mathrm{g} / \mathrm{g})$ & $19.03 \pm 0.03^{a}$ & $19.63 \pm 0.27^{a}$ & $27.36 \pm 0.37^{c}$ & $21.38 \pm 1.67^{a}$ & $21.31 \pm 0.24^{a}$ & $25.00 \pm 0.01^{b}$ \\
\hline Phosphorus (mg/g) & $18.51 \pm 0.01^{a}$ & $19.890 .08^{b}$ & $20.68 \pm 0.55^{b}$ & $21.62 \pm 0.29^{c}$ & $25.50 \pm 0.21^{d}$ & $22.07 \pm 0.05^{\circ}$ \\
\hline
\end{tabular}

Means along the same row with same superscript are not significantly different $(P>0.05)$

Table 3: Proximate and mineral composition of experimental fish before and after feeding trials.

\begin{tabular}{|c|c|c|c|c|c|}
\hline \multirow[b]{2}{*}{ PARAMETERS } & \multicolumn{5}{|c|}{ DIETS } \\
\hline & F1 & F2 & F3 & F4 & F5 \\
\hline Mean initial weight (g) & $1.50 \pm 0.00$ & $1.43 \pm 0.01$ & $1.43 \pm 0.03$ & $1.44 \pm 0.02$ & $1.45 \pm 0.00$ \\
\hline Mean final weight (g) & $7.16 \pm 0.00^{\mathrm{a}}$ & $7.73 \pm 0.14^{b}$ & $8.23 \pm 0.00^{\circ}$ & $9.00 \pm 0.00^{d}$ & $8.15 \pm 0.16^{c}$ \\
\hline Mean weight gain $(\mathrm{g})$ & $5.66 \pm 0.00^{\mathrm{a}}$ & $6.30 \pm 0.13^{b}$ & $6.80 \pm 0.03^{c}$ & $7.56 \pm 0.01^{\mathrm{d}}$ & $6.70 \pm 0.16^{c}$ \\
\hline Total feed fed/Fish (g) & $9.10 \pm 0.00^{\mathrm{a}}$ & $9.62 \pm 0.03^{b}$ & $9.87 \pm 0.03^{c}$ & $10.68 \pm 0.02^{\mathrm{e}}$ & $10.29 \pm 0.08^{d}$ \\
\hline Food conversion ratio (FCR) & $1.60 \pm 0.00^{c}$ & $1.52 \pm 0.03^{b}$ & $1.45 \pm 0.00^{\mathrm{a}}$ & $1.41 \pm 0.00^{\mathrm{a}}$ & $1.53 \pm 0.02^{\mathrm{b}}$ \\
\hline Specific growth rate (SGR) & $3.10 \pm 0.00^{\mathrm{a}}$ & $3.29 \pm 0.03^{b}$ & $3.43 \pm 0.00^{\circ}$ & $3.62 \pm 0.00^{d}$ & $3.40 \pm 0.04^{c}$ \\
\hline Protein efficiency ratio (PER) & $1.45 \pm 0.00^{\mathrm{a}}$ & $1.56 \pm 0.00^{\mathrm{b}}$ & $1.74 \pm 0.01^{\mathrm{c}}$ & $1.78 \pm 0.00^{\mathrm{d}}$ & $1.56 \pm 0.00^{\mathrm{b}}$ \\
\hline$\%$ Bone Ash & $1.38 \pm 0.00^{\mathrm{a}}$ & $1.67 \pm 0.00^{b}$ & $1.76 \pm 0.00^{d}$ & $1.80 \pm 0.01^{e}$ & $1.69 \pm 0.00^{c}$ \\
\hline Bone Phosphorus (mg/g) & $47.00 \pm 1.00^{\mathrm{a}}$ & $50.66 \pm 0.88^{\mathrm{bc}}$ & $50.00 \pm 0.57^{b}$ & $53.00 \pm 0.57^{c}$ & $50.66 \pm 0.88^{b c}$ \\
\hline Parked cell volume (PCV) & $33.33 \pm 0.33^{b}$ & $38.40 \pm 0.70^{c}$ & $35.03 \pm 0.03^{b}$ & $27.30 \pm 0.30^{a}$ & $32.66 \pm 1.45^{b}$ \\
\hline Survival (\%)* & 96.00 & 98.00 & 100.00 & 98.00 & 89.00 \\
\hline
\end{tabular}

Means with same superscript on same row are not significantly different $(P<0.05)$

*No statistical analysis.

Table 4: Growth Performance and Nutrient Utilization of Clarias gariepinus Fed Phytase Supplemented Lima Bean.

\begin{tabular}{|l|l|l|l|l|l|l|}
\hline Parameters & F1 & F2 & F3 & F4 & F5 & MEAN \\
\hline Dissolved Oxygen (mg/l) & 5.40 & 5.30 & 5.44 & 5.34 & 5.41 & 5.37 \\
\hline pH & 7.20 & 7.10 & 7.20 & 7.30 & 7.20 & 7.20 \\
\hline Temperature ( $\left.{ }^{\circ} \mathbf{C}\right)$ & 25.50 & 26.00 & 26.00 & 25.50 & 26.00 & 25.80 \\
\hline
\end{tabular}

Table 5: Mean value of water quality parameters in experimental units.

\begin{tabular}{|l|c|c|c|c|c|}
\hline & \multicolumn{5}{|c|}{ Treatment } \\
\hline Observations & F1 & F2 & F3 & F4 & F5 \\
\hline Macrophage hyperplasia & + & - & - & - & + \\
\hline Lymphotic infilteration & + & + & - & + & - \\
\hline Congestion & - & - & - & + & - \\
\hline
\end{tabular}

- Not Present

+ Moderately Present

Table 6: Liver Response of Fish to Different levels of Phytase-supplemented Lima Bean diet of C. gariepinus.

infiltration moderately occurred in fish in F1, F2 and F4 groups, indicating no particular effect of phytase on organ.

\section{Discussion}

The crude protein content of raw and toasted lima bean of $23.56 \%$ and $23.76 \%$ respectively are similar to results reported by Falaye et al. [16] and Adeparusi and Olute [17]. The complete elimination of trypsin inhibitor by toasting agreed with the report of Ologhobo [18] where heat treatments such as toasting, autoclaving and cooking were shown to destroy heat-labile anti-nutritional factors. However, toasting only resulted in about $10 \%$ reduction in phytate content, which is similar to the $9.3 \%$ reduction reported in Falaye et al. [16].

The proximate composition of the experimental fish showed an increase in crude protein with increasing level of phytase enzyme. This may be attributed to improved availability of nutrients caused by phytase activities. This assertion is supported by Nwanna et al. [12] who reported a high crude protein in fish fed soybean meal diet supplemented with 8000 phytase units.

Zinc, magnesium and calcium deposit in fish fed phytase supplemented diets were significantly higher than in F1 group. Similarly, phosphorus content in fish increased with increasing level of phytase, however, manganese only showed a marginal increase. The result of this present study may be attributed to the efficacy of phytase in breaking the phytate-nutrient bond, causing the availability of more nutrients that were readily utilized by fish. Improved minerals deposition in fish as a result of phytase pretreatment or supplementation in diets have been reported $[9,10,19,20]$. Bone ash and phosphorus concentrations were higher in fish fed phytase supplemented diets, however, increasing the level of supplement did not significantly increase bone phosphorus.

The growth indices showed significantly superior values with phytase supplement. Phytate forms complexes with protein [21] causing depression of protein and amino acids digestion in fish. However the ability of phytase to break such complexes is demonstrated in this present study. This is in consonant the reports of increase in weight, 
Citation: Orisasona O, Ajani EK (2015) The Growth and Mineral Utilization of Clarias Gariepinus Fingerlings Fed Phytase-Supplemented Toasted Lima Bean (Phaseolus lunatus) Diets. J Aquac Res Development 6: 361. doi:10.4172/2155-9546.1000361

length and protein utilization in various fish species fed various plant protein sources supplemented with microbial phytase [10,22-24].

Packed cell volume did not show any particular pattern resulting from phytase supplement, but values recorded fall within the normal ranges reported for C. gariepinus [25-27].

From the results of this present study, it can be deduced that phytase supplementation in fish feed will enhance feed digestibility, thus increasing nutrient availability which will in turn increase growth of cultured fish. The effective utilization of phosphorus by fish fed phytase diets will surely reduce the level of phosphorus released as fecal wastes into the environment, thereby reducing eutrophication in ponds and adjoining water bodies. It could be concluded that the inclusion of 7500 phytase unit in diets with Lima bean (Phaseolus lunatus) as the plant protein source will be beneficial in terms of fish growth and survival.

\section{References}

1. FAO State of World Aquaculture (2006) FAO Fisheries Technical Paper 500 Food and Agriculture Organization of the United Nations. Rome.

2. Tacon AGJ (1995) Fishmeal Replacers: Review of Ant nutrients within Oilseeds and Pulses - A Limiting Factor for the Aqua Feed Green Revolution? FAO, Rome.

3. Gatlin DM, Barrows FT, Dabrowski K, Gaylord TG, Hardy RW et al. (2007) Expanding the utilization of sustainable plant products in aqua-feeds: A review. Aquaculture Research 38: 551-579.

4. Rachie KO, Song L, Lyman S (1980) Lima beans (Phaseolus lunatus) and its potential in the Tropic. In: Summerfield RJ, Bunting AH (eds.) Advances in Legumes Science. Royal Botanical Gardens, Kew, pp. 375-381.

5. Saka JO, Ajibade SR, Adeniyan ON, Olowoyo, RB, Ogunmodede BA (2004) Survey of under-utilised grain legume production system in South-west agricultural zone of Nigeria. J Agriculture and Food Information 6: 93-108.

6. Cheng ZJ, Hardy RW (2003) Effects of extrusion and expelling processing and microbial phytase supplementation on apparent digestibility coefficients of nutrients in full-fat soybeans for rainbow trout (Oncorhynchus mykiss). Aquaculture 218: 501-514.

7. Falaye $A E$, Omoike O, Orisasona O (2014) Apparent Digestibility Coefficient of Differently Processed Lima Bean (Phaseolus lunatus L.) for Clarias gariepinus juveniles. J Fisheries and Aquatic Science 9: 75-84.

8. Cao L, Wang, W, Yang C, Yang Y, Diana J, et al. (2007). Review: Application of microbial phytase in fish feed. Enzyme and Microbial Technology 40: 497-507.

9. VanWeerd JH, Khalaf KH, Aartsen EJ, Tijssen PA (1999) Balance trials with African catfish Clarias gariepinus fed phytase-treated soybean meal-based diets. Aquaculture Nutrition 5: 135-142.

10. Rodehutscord M, Pfeffer E (1995) Effects of Supplemental microbial Phytase on Phosphorus Digestibility and Utilization in Rainbow trout (Oncorhynchus mykiss). Water Science and Technology 31: 141-147.

11. Schafer A, Koppe WM, Meyer-Burgdorff KH, Gunther KD (1995) Effects of Microbial Phytase on Utilization of Native Phosphorus by Carp in Diets based on Soybean Meal. Water Science and Technology 31: 149-155.

12. Nwanna LC, Fagbenro OA, Adeyo AO (2005) Effects of different treatments of dietary soyabean meal and phytase on the growth and mineral deposition in African catfish Clarias gariepinus. Journal of Animal and Veterinary Advances 4: $980-987$.
13. Castell JD, Tiews K (1980) Report of the EIFAC, IUNs and ICES working group on standardisation of methodology in fish nutrient research. Hamburg, Fed. Republic of Germany, EIFAC Tech, Germany.

14. Association of Official Analytical Chemists (2005) Official Methods of Analysis (17thedn.) AOAC, Washington, DC, USA.

15. Duncan DB (1955) Multiple Range and F Tests. Biometrics 11: 1-42.

16. Orisasona O, Falaye AE, Ajani EK (2014) Effect of replacement of Soya Bean Meal with Lima Bean Meal on the Growth and Heamatological parameters of C. gariepinus fingerlings (Burchell 1822) Israeli journal of Aquaculture-Bamidgeh. In press.

17. Adeparusi EO, Olute BW (2002) Effects of Methionine-supplemented toasted Lima Bean (Phaeolus lunatus) Diets on Growth of Oreochromis niloticus.

18. Ologhobo AD (1992) Nutritive value of some tropical (West Africa) Legumes for Poultry. J Appl Animal Res 2: 93-104.

19. Sugiura SH, Gabaudan J, Dong FM, Hardy RW (2001) Dietary microbial phytase supplementation and the utilization of phosphorus, trace minerals and protein by rainbow trout (Oncorhynchus mykiss. Walbaum) fed soybean mealbased diets. Aqua Res 32: 583-592.

20. Nwanna LC, Kolasha M, Eisenreich R, Schwarz FJ (2007) Pretreatment of dietary plant feedstuffs with phytase and its effect on growth and minera concentration in common carp (Cyprinus carpio L.). J Animal Physiology and Nutrition 92: 677-682.

21. Riche M, Garling DL (2004) Effect of phytic acid on growth and nitrogen retention in tilapia. Oreochromis niloticus L. Aquaculture Nutrition 10: 389-400.

22. Menghe HL, Bruce BM, Edwin HR (2004). Summary of Phytase Studies for Channel Catfish. Mississippi Agric. And Forestry Experiment Station. Research Report 23.

23. Soares JH, Hughes KP (1994) Efficacy of Phytase on Phosphorus Utilization. Proc Of Maryland Nutrition Conf.

24. Ketola GH (1994) Use of enzymes in Diets of Trout to reduce environmental discharges of Phosphorus. World aquaculture 94: 1-94.

25. Erondu ES, Nubia S, Nwadukwe FO (1993) Hematological studies on four Catfish species raised in Fresh water pond in Nigeria. Journal of Allied Ichthyology 9: 250-256.

26. Musa SO, Omoregie E (1999) Hematological changes in Mudfish, Clarias gariepinus (Burchell) exposed to Malachite green. Journal of Aquatic Sciences 14: $37-42$.

27. Nwanna LC (2007) Effect of dietary phytase on growth, enzyme activities and phosphorus load of Nile Tilapia (Oreochromis niloticus). Journal of Engineering and Applied Sciences 2: 972-976. 